\title{
Using Leaves of Oriental Plane (Platanus orientalis L.) to Determine the Effects of Heavy Metal Pollution Caused by Vehicles
}

\author{
Halil Barış Özel'*, Handan Ucun Özel², Tuğrul Varol ${ }^{3}$ \\ 'Department of Silviculture, Faculty of Forestry, \\ ${ }^{2}$ Department of Environmental Engineering, Faculty of Engineering, \\ ${ }^{3}$ Department of Forest Engineering, Faculty of Forestry, \\ Bartın University, 74100 Bartın, Turkey \\ Received: July 6, 2015 \\ Accepted: August 12, 2015
}

\begin{abstract}
This study uses oriental plane (Platanus orientalis L.) leaves to determine the heavy metal pollution caused by vehicular traffic on the D-755 Highway connecting Bartın and Karabük cities in Turkey. As a result of the analyses, it was determined that the order of elements leading to metal emitted from vehicles is $\mathrm{Pb}>\mathrm{Zn}>\mathrm{Ni}>\mathrm{Cu}>\mathrm{Cr}>\mathrm{Cd}$. On the other hand, according to the variance analysis and Duncan test performed, we found a statistically significant difference between 20 sampling stations at the confidence level of $\mathrm{P}<0.01$. Accordingly, while stations $1,2,3,4,10,11,17,18,19$, and 20 were in the first group in terms of heavy metal pollution, stations $5,6,7,8,9,12$, and 13 were in the second group, and stations 14,15 , and 16 were in the third group. Moreover, it was determined that injuries at dimensions of 1.5-4.7 $\mu \mathrm{m}$ occurred in epidermis cells of the oriental plane trees' leaves, and that the dimensions of these injuries reached levels of 10.2-14.7 $\mu \mathrm{m}$ during further periods. Actual levels of trace elements are as follows: $\mathrm{Pb} 0.10-0.78 \mathrm{mg} \cdot \mathrm{kg}^{-1}, \mathrm{Zn} 18.2-52.4 \mathrm{mg} \cdot \mathrm{kg}^{-1}$, Ni 0.13-0.35 mg.kg-1 Cu 3.45-12.73 $\mathrm{mg} \cdot \mathrm{kg}^{-1}$, Cr 0.21-0.37 $\mathrm{mg} \cdot \mathrm{kg}^{-1}$, and Cd 0.05-0.12 $\mathrm{mg} \cdot \mathrm{kg}^{-1}$.
\end{abstract}

Keywords: heavy metal, motor vehicle pollution, oriental plane, epidermis

\section{Introduction}

Important as they are, motor vehicles pollute the environment. The air pollution they cause is a serious issue that was discussed for many years and that requires measuring the pollution during manufacturing and operation [1]. Especially in large cities, the number of vehicles per capita is increasing day by day. As of 2010, there are 953.4 million motor vehicles in the world; 14.3 million of them can be found in Turkey [2].

Motor vehicles are responsible for a major portion of air pollution. The pollutants released from the motor vehicles are carbon monoxide, carbon dioxide, hydrocarbons, nitrogen

*e-mail: halilbarisozel@yahoo.com oxides, sulfur oxides, soot in particle form, and some heavy metals. The main heavy metal pollutants caused by traffic are lead $(\mathrm{Pb})$, nickel $(\mathrm{Ni})$, mercury $(\mathrm{Hg})$, cadmium $(\mathrm{Cd})$, zinc $(\mathrm{Zn})$, chromium $(\mathrm{Cr})$, and copper $(\mathrm{Cu})$. Lead $(\mathrm{Pb})$ originates from the tetra-ethyl-lead (TEL) added into the petrol in order to eliminate the pinking in motor vehicles, and nickel (Ni) arises mainly from diesel fuel and motor oils. Cadmium $(\mathrm{Cd})$ and zinc $(\mathrm{Zn})$ originate from vehicle tires, oils, and other vehicle components - especially diesel fuel [3].

Because of the lack of technical maintenance of the vehicles in urban traffic, unconscious usage of them, and the presence of very old vehicles, the pollutant character of them rises twofold, and they become an important pollution source. Air pollution is one of the elements of the environmental pollution - and the most important. 
Air has certain portions, and polluting the air means deteriorating these ratios. Air pollution is an important environmental pollution, which we face globally from the region where we actually live. It directly or indirectly deteriorates almost all the systems of our world, damaging and irrevocably affecting them. Human health, plant and forest destruction, agricultural yield losses, climate change, and the extinction of civilizations are the first scenarios coming to mind. Preventing air pollution and achieving breathable air requires cooperation at every level. A sustainably clear air quality level can be achieved through efforts made via cooperation and organizations between individuals, governments, and nations. These efforts should be started at the individual level and continue globally. As an individual, we have many things to do in order to decrease the amounts of air pollutants. The little changes in our personal preferences and energy use will significantly contribute to the improvement of air quality.

Most respiratory tract diseases leading to death are caused by air pollution. The effects of air pollution on human health arise due to the high levels of harmful materials in the atmosphere. In order for humans to live healthy and comfortable lives, the air must be absolutely clean. Respiring the polluted air may be destructive for lung tissues, and even lethal. The particles and fumes are taken through respiration, when they reach the lungs. It was revealed that $70-90 \%$ of carbon monoxide, $40-70 \%$ of nitrogen oxide, $50 \%$ of hydrocarbons, and $100 \%$ of lead emissions originate from motor vehicles [4].

Together with industrialization and increasing human activity, pollution occurs in the environment, and different harmful materials enter into the atmosphere. As a result, the heavy metals that are harmful to human health such as lead $(\mathrm{Pb})$, zinc $(\mathrm{Zn})$, copper $(\mathrm{Cu})$, chromium $(\mathrm{Cr})$, cobalt $(\mathrm{Co})$, and cadmium $(\mathrm{Cd})$, etc., accumulate in the air, water, soil, and plants, and this process comes up as pollution. These heavy metals are toxic. In parallel with the rapidly increasing global population, urbanization, and industrialization, environmental pollution has gained importance in our country, and air pollution has made itself evident, especially in our large cities. Besides the air pollution arising from the fixed emission sources such as houses and industrial corporations, air pollution originating from motor vehicles also has become an important problem.

Today it is known that various motor vehicles release heavy metals such as $\mathrm{Pb}, \mathrm{Cd}, \mathrm{Ni}, \mathrm{Cr}, \mathrm{Cu}$, and $\mathrm{Zn}$, even in trace amounts. In parallel with the construction of new highways, the heavy metal load released to the atmosphere increases gradually in parallel with the increase in the number of vehicles in traffic. This also affects agricultural lands. Heavy metal pollution is observed especially in the plants that grow alongside the main roads and highways. All these factors polluting the environment lead to stress in the plants. It is known that heavy metals directly or indirectly affect the physiological functions and biochemical events in plants, especially after certain doses. High levels of heavy metal accumulation in plant tissues negatively affects many things such as mineral nutrition intake, photosynthesis, transpiration, enzyme activity, nucleic acid structure, chlorophyll biosynthesis, and germination [5]. Moreover, cell membrane damage, deteriorated hormone balance, and change in water relationships can be added. Revealing how heavy metal stress affects the metabolic activities of the plants, which reactions the plants give to these pollutants, and which adjustment mechanisms they develop is very important. So, the size of the problem can be better understood. And this allows precautions to be taken and future plans to be healthier. In recent years, for preventing or minimizing the harmful effects of toxic metals such as lead, the use of natural bio-indicators in observing the quality of the atmosphere in urban and rural areas has significantly increased. Among biological materials, the most preferred are fungus, lichen, bryophytes, tree bark, annual rings, and the leaves of annual and perennial plants.

In order for a species to be used as a bio-monitor in determining heavy metal pollution, there are some fundamental criteria. These are to be widely represented in the collection zone, to have a wide geographic distribution, easy sampling, and absence of identity problems [5]. The aim of this study, by using the oriental plane (Platanus orientalis $\mathrm{L}$.) species as a biological indicator to determine the extent of heavy metal pollution caused by the intense traffic along a $110 \mathrm{~km}$ stretch of the D-755 State Highway between Bartın and Karabük.

\section{Material and Methods}

\section{Determining Vehicle Density}

In order to determine the number of vehicles passing through the D-755 highway, four sensor-fitted night-view cameras were placed at the starting and end points of the road. By these cameras, the traffic density on D-755 was determined.

\section{Determining the Sampling Stations and Sampling}

In order to determine the heavy metal pollution caused by vehicle traffic along the D-755 Highway between Bartın and Karabük, triplicated sampling stations were established alongside the road at $5 \mathrm{~km}$ intervals. Within this context, a total of 20 sampling stations were established (Fig. 1). Leaf samples were taken from every oriental plane tree in sampling stations. While collecting leaf samples, we took samples from five oriental plane trees at each station, and took leaf samples from a total of 50 trees. For the control group, leaf samples were taken from the oriental plane trees $500 \mathrm{~m}$ from the highway. While collecting the leaf samples we used sterile plastic gloves, and then the samples were put into sterile bags and taken to the laboratory.

\section{Determining the Heavy Metal Amounts}

The leaf samples taken from the oriental plane trees in each of the stations were taken into the laboratory on the same day, washed with distilled water sequentially, and then dried in a drying oven at $60^{\circ} \mathrm{C}$. The washed and dried 
leaf samples were ground homogenously via a plastic grinder. The mineralization of the samples was performed via a microwaving system. For this purpose, $1 \mathrm{~g}$. of dried leaf sample was taken in a container, then $15 \mathrm{~mL}$ of nitric acid at $70 \%$ concentration was added, and they were broken down by stirring for 3 hours at $65^{\circ} \mathrm{C}$. After cooling, the nitric acid in the samples was evaporated, and then $20 \mathrm{~mL}$ of pure water was added. Then, after filtering, the samples were filled to $30 \mathrm{~mL}$ and finally the amounts of the heavy metals were determined via ICP-OES and ICP-MS devices [6]. The heavy metal concentrations of the leaf samples taken from each of the stations was measured sequentially five times, and the average value was calculated [5].

\section{Determining the Damage on Leaf Tissues and Cells}

In order to determine the damage to the leaf samples taken from oriental plane trees caused by highway traffic, a scanning electron microscope was utilized. For this purpose, a QUANTA 400F Field Emission scanning electron microscope was used. Within this context, the leaf samples were kept in a drying oven for 48 hours. After washing the gelatin on the samples taken from the drying oven with hot water, the semi-thin sections were taken via a $2 \mu \mathrm{m}$-thick diamond knife. In order to prepare the preparation required for imaging with the scanning electron microscope, $60 \mathrm{~nm}$ thick sections were taken from the previously taken sections. The thin sections collected into the pool were passed from xylolization for flattening the wrinkles. In the xylolization process, the xylol was approximated to the tissues via water color brush, and the wrinkles were flattened via the smell of the xylol. Then the grids, where sections were taken, were dried, and then placed into the grid box. Thin sections were examined in the scanning electron microscope by staining with uranyl-acetate and lead-citrate stains [7].

\section{Statistical Analyses}

In analyses of the data obtained from the experiments on the leaf samples, variance analysis (ANOVA) and

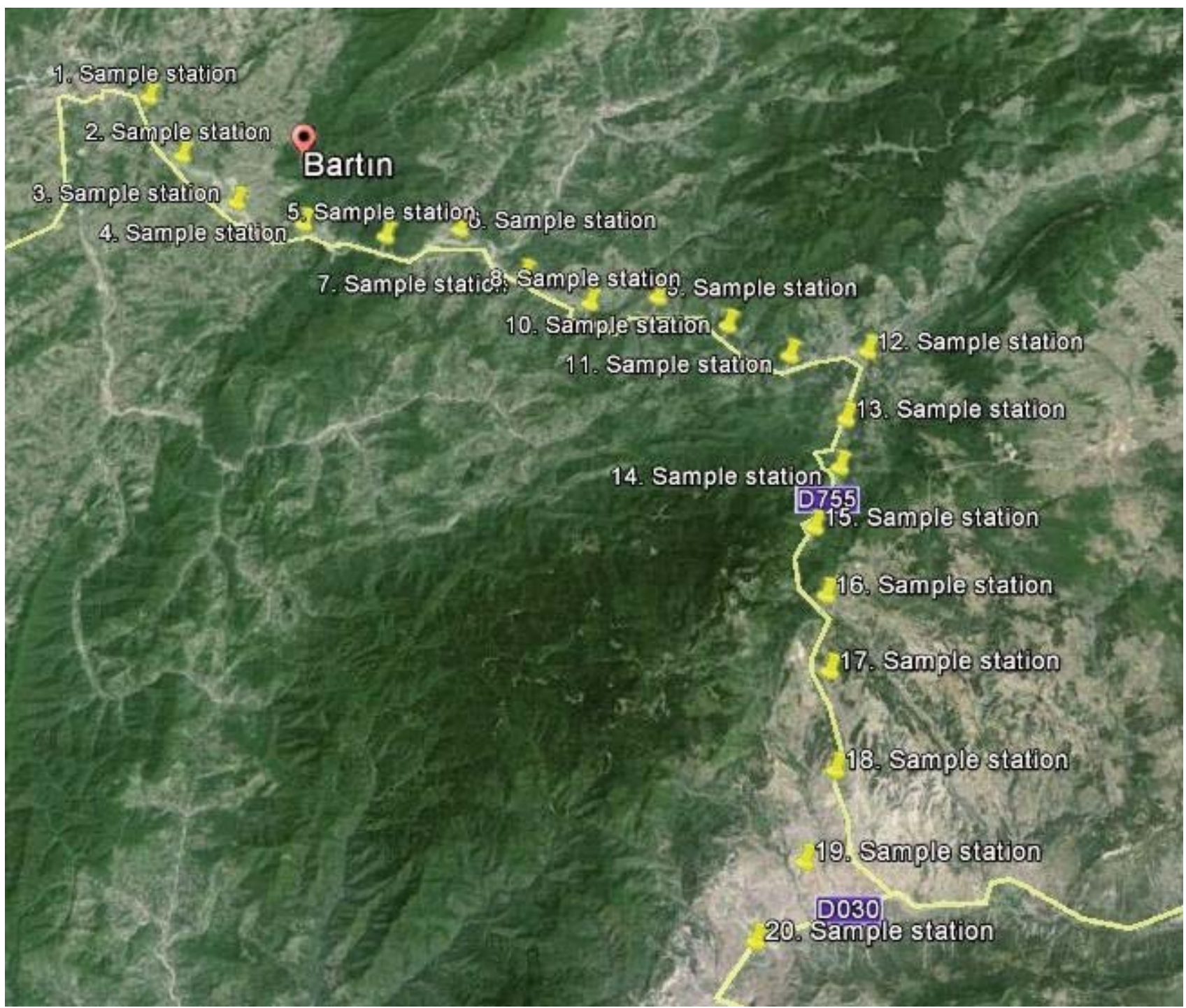

Fig. 1. Distribution of sampling stations throughout D-755 Highway. 
Table 1. Motor vehicle density in Bartın-Karabük highway during 2014.

\begin{tabular}{|c|c|}
\hline Car & 18,443 \\
\hline Bus & 11,562 \\
\hline Truck & 13,678 \\
\hline Pick-Up & 5,642 \\
\hline TIR & 21,576 \\
\hline Total & 52,843 \\
\hline
\end{tabular}

Duncan Test were utilized. ANOVA test was applied to data followed by Duncan test to examine the difference between means. Both of the statistical analysis methods were performed at the confidence level of $99 \%$. For this purpose, SPSS statistical analysis package software was utilized.

\section{Results}

\section{Results Related to Vehicle Density}

Through the sensor-fitted cameras, the number of vehicles that passed through the D-755 Highway in year 2014 was determined, and is presented in Table 1.

As can be seen in these values (related to density and types of vehicles) in Table 1, the highest portion of the motor vehicle traffic during 2014 consisted of TIRs, followed by cars, trucks, buses, and pick-ups.

\section{Heavy Metal Pollution Determined in Leaf Samples}

The heavy metal contents determined in oriental plane leaf samples collected from 30 stations on D-755 and the results of variance analysis and Duncan test are presented in Table 2. Given the values in Table 2, as a result of the

Table 2. Variance analysis $(\mathrm{P}<0.01)$ and Duncan test $(\mathrm{P}<0.01)$ results of heavy metal pollution determined in Oriental plane leaves $(\mathrm{P}<0.01)$.

\begin{tabular}{|c|c|c|c|c|c|c|}
\hline \multirow{3}{*}{$\begin{array}{l}\text { Sampling } \\
\text { station }\end{array}$} & \multicolumn{6}{|c|}{ Heavy metals $\left(\mathrm{mg} \cdot \mathrm{kg}^{-1}\right)$} \\
\hline & $\mathrm{P}<0.01$ & $\mathrm{P}<0.01$ & $\mathrm{P}<0.01$ & $\mathrm{P}<0.01$ & $\mathrm{P}<0.01$ & $\mathrm{P}<0.01$ \\
\hline & $\mathrm{Pb}$ & $\mathrm{Zn}$ & $\mathrm{Ni}$ & $\mathrm{Cu}$ & $\mathrm{Cr}$ & $\mathrm{Cd}$ \\
\hline 1 & $87.63 \pm 2.3^{\text {a* }}$ & $65.23 \pm 2.8^{\mathrm{a}}$ & $35.28 \pm 3.2^{\mathrm{a}}$ & $21.18 \pm 3.2^{\mathrm{a}}$ & $11.45 \pm 2.2^{\mathrm{a}}$ & $0.90 \pm 0.64^{\mathrm{a}}$ \\
\hline 2 & $88.76 \pm 2.1^{\mathrm{a}}$ & $67.54 \pm 2.5^{\mathrm{a}}$ & $37.64 \pm 3.4^{\mathrm{a}}$ & $21.36 \pm 3.3^{\mathrm{a}}$ & $12.62 \pm 2.3^{\mathrm{a}}$ & $0.92 \pm 0.68^{\mathrm{a}}$ \\
\hline 3 & $90.33 \pm 2.4^{\mathrm{a}}$ & $69.72 \pm 2.6^{\mathrm{a}}$ & $38.43 \pm 3.2^{\mathrm{a}}$ & $23.65 \pm 3.3^{\mathrm{a}}$ & $13.23 \pm 2.3^{\mathrm{a}}$ & $0.93 \pm 0.72^{\mathrm{a}}$ \\
\hline 4 & $91.48 \pm 2.3^{\mathrm{a}}$ & $72.48 \pm 2.5^{\mathrm{a}}$ & $39.65 \pm 3.3^{\mathrm{a}}$ & $23.72 \pm 3.4^{\mathrm{a}}$ & $13.75 \pm 2.4^{\mathrm{a}}$ & $0.93 \pm 0.81^{\mathrm{a}}$ \\
\hline 5 & $72.36 \pm 3.8^{\mathrm{b}}$ & $54.43 \pm 3.1^{\mathrm{b}}$ & $26.35 \pm 4.2^{\mathrm{b}}$ & $17.54 \pm 2.7^{\mathrm{b}}$ & $7.65 \pm 1.4^{\mathrm{b}}$ & $0.65 \pm 0.52^{\mathrm{b}}$ \\
\hline 6 & $73.42 \pm 3.5^{\mathrm{b}}$ & $56.65 \pm 3.2^{\mathrm{b}}$ & $27.34 \pm 4.3^{\mathrm{b}}$ & $17.62 \pm 2.8^{\mathrm{b}}$ & $7.78 \pm 1.5^{\mathrm{b}}$ & $0.68 \pm 0.55^{\mathrm{b}}$ \\
\hline 7 & $69.45 \pm 3.3^{b}$ & $57.43 \pm 3.2^{\mathrm{b}}$ & $28.42 \pm 4.2^{\mathrm{b}}$ & $18.63 \pm 2.6^{\mathrm{b}}$ & $8.21 \pm 1.7^{\mathrm{b}}$ & $0.70 \pm 0.58^{b}$ \\
\hline 8 & $69.23 \pm 3.6^{\mathrm{b}}$ & $58.16 \pm 3.5^{\mathrm{b}}$ & $29.57 \pm 4.4^{\mathrm{b}}$ & $19.27 \pm 2.6^{\mathrm{b}}$ & $8.36 \pm 1.7^{\mathrm{b}}$ & $0.72 \pm 0.63^{\mathrm{b}}$ \\
\hline 9 & $68.76 \pm 3.5^{\mathrm{b}}$ & $59.88 \pm 3.4^{\mathrm{b}}$ & $33.68 \pm 4.5^{\mathrm{b}}$ & $19.48 \pm 2.5^{\mathrm{b}}$ & $8.44 \pm 1.8^{\mathrm{b}}$ & $0.73 \pm 0.57^{\mathrm{b}}$ \\
\hline 10 & $86.92 \pm 4.2^{\mathrm{a}}$ & $66.51 \pm 3.5^{\mathrm{a}}$ & $36.47 \pm 3.5^{\mathrm{a}}$ & $23.57 \pm 3.4^{\mathrm{a}}$ & $11.78 \pm 2.4^{\mathrm{a}}$ & $0.87 \pm 0.65^{\mathrm{a}}$ \\
\hline 11 & $85.74 \pm 3.6^{\mathrm{a}}$ & $68.76 \pm 3.4^{\mathrm{a}}$ & $38.83 \pm 3.4^{\mathrm{a}}$ & $24.32 \pm 3.5^{\mathrm{a}}$ & $12.45 \pm 2.5^{\mathrm{a}}$ & $0.88 \pm 0.72^{\mathrm{a}}$ \\
\hline 12 & $68.56 \pm 4.3^{\mathrm{b}}$ & $53.26 \pm 3.2^{\mathrm{b}}$ & $24.18 \pm 4.2^{\mathrm{b}}$ & $17.72 \pm 2.6^{\mathrm{b}}$ & $8.15 \pm 1.8^{\mathrm{b}}$ & $0.52 \pm 0.45^{b}$ \\
\hline 13 & $67.75 \pm 4.1^{\mathrm{b}}$ & $53.34 \pm 3.3^{\mathrm{b}}$ & $26.34 \pm 4.2^{\mathrm{b}}$ & $17.83 \pm 2.7^{b}$ & $8.34 \pm 1.8^{\mathrm{b}}$ & $0.58 \pm 0.47^{b}$ \\
\hline 14 & $55.64 \pm 4.4^{\mathrm{c}}$ & $42.16 \pm 2.7^{c}$ & $15.48 \pm 2.6^{c}$ & $10.42 \pm 2.2^{\mathrm{c}}$ & $4.32 \pm 1.4^{c}$ & $0.21 \pm 0.02^{c}$ \\
\hline 15 & $57.87 \pm 4.3^{\mathrm{c}}$ & $43.58 \pm 2.9^{c}$ & $15.67 \pm 2.5^{\mathrm{c}}$ & $10.57 \pm 2.3^{c}$ & $4.38 \pm 1.5^{\mathrm{c}}$ & $0.23 \pm 0.06^{\mathrm{c}}$ \\
\hline 16 & $58.42 \pm 4.5^{\mathrm{c}}$ & $44.64 \pm 3.3^{c}$ & $16.43 \pm 2.8^{c}$ & $11.43 \pm 2.3^{\mathrm{c}}$ & $5.26 \pm 1.5^{\mathrm{c}}$ & $0.27 \pm 0.14^{\mathrm{c}}$ \\
\hline 17 & $89.63 \pm 3.2^{\mathrm{a}}$ & $71.18 \pm 3.1^{\mathrm{a}}$ & $38.56 \pm 3.2^{\mathrm{a}}$ & $21.45 \pm 3.1^{\mathrm{a}}$ & $12.74 \pm 2.2^{\mathrm{a}}$ & $0.91 \pm 0.75^{\mathrm{a}}$ \\
\hline 18 & $92.35 \pm 3.4^{\mathrm{a}}$ & $73.29 \pm 3.3^{\mathrm{a}}$ & $39.23 \pm 3.3^{\mathrm{a}}$ & $21.88 \pm 3.2^{\mathrm{a}}$ & $12.95 \pm 2.3^{\mathrm{a}}$ & $0.93 \pm 0.78^{\mathrm{a}}$ \\
\hline 19 & $95.56 \pm 3.3^{\mathrm{a}}$ & $75.56 \pm 3.2^{\mathrm{a}}$ & $39.42 \pm 3.4^{\mathrm{a}}$ & $23.57 \pm 3.4^{\mathrm{a}}$ & $13.15 \pm 2.4^{\mathrm{a}}$ & $0.93 \pm 0.82^{\mathrm{a}}$ \\
\hline 20 & $96.84 \pm 3.5^{\mathrm{a}}$ & $75.63 \pm 3.3^{\mathrm{a}}$ & $42.29 \pm 3.3^{\mathrm{a}}$ & $23.62 \pm 3.3^{\mathrm{a}}$ & $13.47 \pm 2.4^{\mathrm{a}}$ & $0.94 \pm 0.88^{a}$ \\
\hline \multirow[t]{2}{*}{ Control } & $07.16 \pm 2.3^{\mathrm{d}}$ & $05.28 \pm 1.6^{\mathrm{d}}$ & $04.52 \pm 2.1^{\mathrm{d}}$ & $0.87 \pm 1.16^{\mathrm{d}}$ & $04.42 \pm 1.7^{\mathrm{d}}$ & $0.00 \pm 0.00^{\mathrm{d}}$ \\
\hline & $\mathrm{A}^{*}$ & A & A & B & B & $\mathrm{C}$ \\
\hline
\end{tabular}

*Each of the groups is represented by a different letter.

The bold values of each column are indicating minimum and maximum values of heavy metals species determination in the research area. 
variance analysis, a statistically significant difference was found between the leaf sampling stations at the confidence level of $\mathrm{P}<0.01$. According to the results of Duncan Test performed at the confidence level of $\mathrm{P}<0.01$, while stations $1,2,3,4,10,11,17,18,19$, and 20 were in the first group in terms of heavy metal pollution, stations $5,6,7,8,9,12$, and 13 were in the second group, and stations 14, 15, and 16 were in the third group. The stations where the heavy metal pollution level was at its highest values were the stations located near Bartın and Karabük, which are at the start and end points of D-755 and the Bartın Organized Industrial Region, where there is very intense traffic.

On the other hand, as a result of performed variance analysis, a statistically significant difference was found between the heavy metal elements at the confidence level of $\mathrm{P}<0.01$. As a result of the Duncan Test performed in this parallel, it was determined that $\mathrm{Pb}$ and $\mathrm{Zn}$ are in the first group, while $\mathrm{Ni}, \mathrm{Cu}$, and $\mathrm{Cr}$ are in the second group, and $\mathrm{Cd}$ in the third (Table 2). Moreover, a statistically significant difference was found in the amounts of these heavy metal elements between the stations at the confidence level of $\mathrm{P}<0.01$. As a result of the Duncan test performed at confidence level of $\mathrm{P}<0.01$ for this purpose, it was determined that $\mathrm{Pb}, \mathrm{Zn}$, and $\mathrm{Ni}$ take place in the first rank, followed by $\mathrm{Cu}, \mathrm{Cr}$, and $\mathrm{Cd}$ (Table 2).

\section{Heavy-Metal-Caused Damage to Leaf Epidermal Cells}

Within the framework of our study, we also tried to determine the damage by heavy metals to cells of the leaves taken from 20 stations throughout the highway. For this pur- pose, the thin sections taken from the oriental plane leaves that have and have not been damaged by the heavy metals caused from the highway traffic were examined under the scanning electron microscope. According to the results, it was determined that injuries at dimensions of 1.5-4.7 $\mu \mathrm{m}$ occurred in epidermis cells of the surface of the trees' leaves, and that the dimensions of these injuries reached levels of 10.2-14.7 $\mu \mathrm{m}$ during further periods (Fig. 2).

\section{Discussion}

By considering the starting and ending points of the $110-\mathrm{km}$ stretch of highway, a total of 20 sampling stations were selected at $5-\mathrm{km}$ intervals, and the leaf samples were collected from a total of 50 trees throughout the road. Moreover, in order to obviously and objectively reveal the effects of heavy metal pollution caused by vehicle traffic, leaf samples were analyzed in triplicate from 20 trees chosen as control $500 \mathrm{~m}$ from the road.

As a result of analyses performed on the leaf samples via ICP-OES and ICP-MS devices, it was determined that there was a statistically significant difference between 20 stations at the confidence level of $\mathrm{P}<0.01$. Moreover, according to the results of Duncan Test performed at the confidence level of $\mathrm{P}<0.01$, stations $1,2,3,4,10,11,17$, 18,19 , and 20 were in the first group in terms of heavy metal pollution, while stations $5,6,7,8,9,12$, and 13 were in the second group, and stations 14,15 , and 16 were in the third group (Table 2). Since they are located at the starting and ending points of the roads and at the organized industrial region, the stations in the first group are subjected to
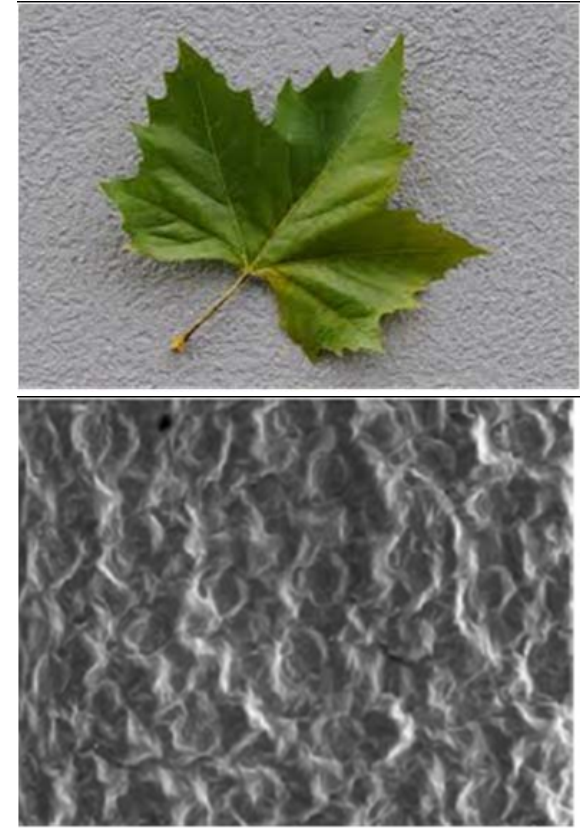

A
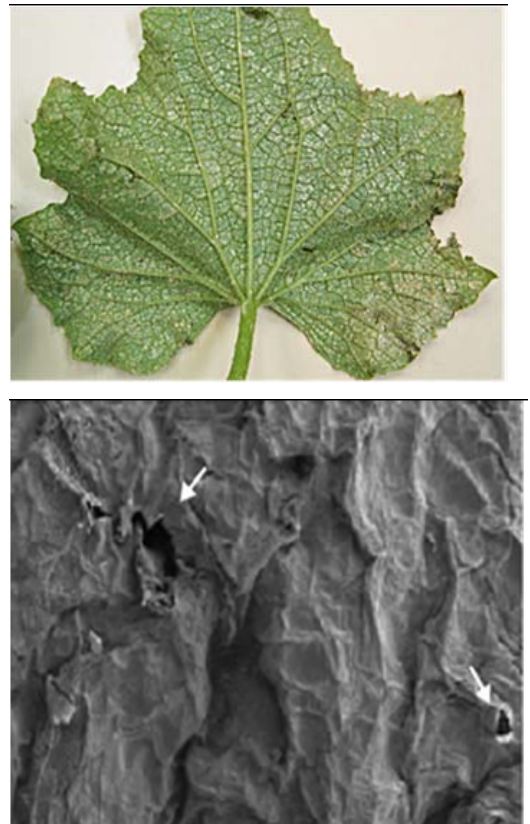

B

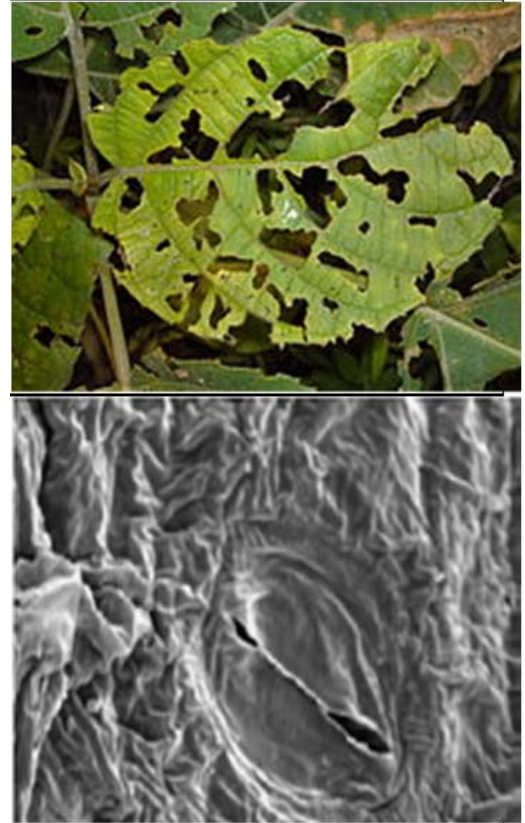

C

Fig. 2. The types of damage to Oriental plane leaves caused by heavy metal pollution originating from vehicle traffic and the SEM images of the damaged epidermis cells $(20 \mu \mathrm{n})$.

A - Healthy leaf, B - Epidermis cells damaged at mild level (white arrows), and C - Severely damaged epidermis cells 
higher traffic intensities, and consequently the heavy metal pollution and damages determined on the leaf samples taken from these points were higher than those determined in other stations. In another study that was carried out on this topic along the Black Sea coastline, it was determined that the vehicular heavy metal pollution level is higher in plant samples taken from exit points of the cities and regions near industrial zones [5].

In another study that was carried out along the Viranşehir-Kızıltepe Highway in Turkey, similar results were obtained [3]. In another study, it was determined via the air pollution models developed that the heavy metal pollution caused from the intense vehicle traffic led to significant damage to the crown development and leaf surfaces of Acer pseudoplatanus and Quercus robur species located 30-70 km from the city centers [8].

In a study in Bangladesh, it was determined that, due to the more intense traffic in the roads passing through or near the industrial zones than the ones on other courses, heavy metals such as $\mathrm{Pb}$ and $\mathrm{Zn}$ that are released by traffic lead to significant damage to the physiological and morphological characteristics of tall and shrubby plants, and that these damages cannot be easily tolerated by the plants [9].

As a result of analysis of the extracts prepared from the leaf samples taken from the oriental plane trees on the roadside and those $500 \mathrm{~m}$ from the road (control), $\mathrm{Pb}, \mathrm{Zn}, \mathrm{Ni}$, $\mathrm{Cu}, \mathrm{Cr}$, and $\mathrm{Cd}$ heavy metal elements were determined, respectively. Thus, as a result of the variance analysis applied to the heavy metal elements, a statistically significant difference was found between the heavy metals at the confidence level of $\mathrm{P}<0.01$. Moreover, as a result of Duncan test performed in this parallel, it was determined that $\mathrm{Pb}$ and $\mathrm{Zn}$ are in the first group, $\mathrm{Ni}, \mathrm{Cu}$, and $\mathrm{Cr}$ are in the second group, and $\mathrm{Cd}$ is in the third group (Table 2). Moreover, a statistically significant difference was found in the amounts of these heavy metals between the sampling stations at the confidence level of $\mathrm{P}<0.01$. As a result of Duncan test at confidence level of $\mathrm{P}<0.01$, it was found that $\mathrm{Pb}, \mathrm{Zn}$, and Ni take place on the first rank in all the stations, followed by $\mathrm{Cu}, \mathrm{Cr}$, and $\mathrm{Cd}$. Thus, it was determined that the amounts of $\mathrm{Pb}$ ranged between 55.64 and $96.84 \mathrm{mg} \cdot \mathrm{kg}^{-1}, \mathrm{Zn}$ between 42.16 and $75.63 \mathrm{mg} \cdot \mathrm{kg}^{-1}$, Ni $15.48-42.29 \mathrm{mg} \cdot \mathrm{kg}^{-1}$, $\mathrm{Cu}$ 10.42-23.72 $\mathrm{mg} \cdot \mathrm{kg}^{-1}, \mathrm{Cr} 4.32-13.75 \mathrm{mg} \cdot \mathrm{kg}^{-1}$, and $\mathrm{Cd}$ 0.21-0.94 $\mathrm{mg} \cdot \mathrm{kg}^{-1}$. On the other hand, the station having the lowest level of heavy metal concentration among all the stations was found to be No. 14 - the one closest to natural forest sources (Table 2). Within this context, it was revealed that the concentrations of $\mathrm{Pb}, \mathrm{Zn}$, and $\mathrm{Ni}$ are the highest among all the heavy metals according to the results of statistical analyses. As a reason for this situation, the leaded fuel and oil use of TIRs, trucks, cars, and buses passing from D-755 (Table 1) can be shown.

Another study in the Black Sea region tried to determine the level of heavy metal pollution caused from the intense vehicle traffic, and it was determined that the levels of $\mathrm{Pb}, \mathrm{Zn}$, and $\mathrm{Ni}$ heavy metals concentrations on the surface of plant leaves were higher than other heavy metal elements [5].
In a study carried out on 12 plant species in England, the dimensions of the heavy metal pollution caused from the intense highway traffic were examined, and $\mathrm{Ni}$ with $88.4 \mathrm{mg} \cdot \mathrm{kg}^{-1}$ concentration, $\mathrm{Pb}$ with $81.6 \mathrm{mg} \cdot \mathrm{kg}^{-1}$ concentration, and $\mathrm{Zn}$ with $73.2 \mathrm{mg} \cdot \mathrm{kg}^{-1}$ concentration were found to be the heavy metals having the highest contributions to air metal pollution $[6,10]$.

In another study carried out in India using the leaves of Saraca indica L., Azardirachta indica L., Tamarindus indica Asc., and Nerium odoroum L. species located on the roadside, the heavy metal pollution caused from the highway traffic was examined, and the heavy metals having the highest contribution to the pollution were found to be $\mathrm{Ni}$ with $72.5 \mathrm{mg} \cdot \mathrm{kg}^{-1}$ concentration, and $\mathrm{Pb}$ with $63.8 \mathrm{mg} \cdot \mathrm{kg}^{-1}$ concentration [11]. In another study carried out along the Viranşehir-Kızıltepe Highway in Turkey, the highest contributions on the heavy metal pollution caused from the motor vehicles were found to belong to $\mathrm{Ni}$ with a concentration of $42 \mathrm{mg} \cdot \mathrm{kg}^{-1}, \mathrm{~PB}$ with a concentration of $28 \mathrm{mg} \cdot \mathrm{kg}^{-1}$, and $\mathrm{Cr}$ with a concentration of $14 \mathrm{mg} \cdot \mathrm{kg}^{-1}$ [3].

In this study, where the levels and effects of vehicular heavy metal pollution on D-755 were examined, the damages that occur in the leaf cells of oriental plane trees that were used for bio-monitoring were determined as a result of examining the complete thin sections, which were taken from the leaves, under a scanning electron microscope. According to these examinations, it was determined that injuries at dimensions of 1.5-4.7 $\mu \mathrm{m}$ occurred in epidermis cells of the oriental plane trees' leaves, and that the dimensions of these injuries reached the levels of 10.2-14.7 $\mu \mathrm{m}$ during further periods (Fig. 2).

Hence, the plant physiologists state that the heavy metals lead to significant decreases firstly on the epidermis cells that are closest to the leaf surface, decreases in photosynthesis levels by deteriorating the leaf physiology of the plant, and drying of the plants through metabolism deterioration caused from severe levels of injuries in the leaf surface $[12,13]$.

In another study, where the effects of heavy metal pollution originating from highway traffic were examined in Romania, the leaves of Tilia tomentosa L., Tilia cordata L. and Tilia platyphyllo L. species were used, and it was determined that injuries at sizes of 18.6-35.4 $\mu \mathrm{m}$ occurred in epidermis cells of leaf samples and the cuticle cells at the bottom layer, that these injuries couldn't be healed by the plants for a year, and that these bio-monitoring species seared significantly due to these injuries [14].

\section{Conclusion}

The present investigation clearly showed that there was a strong relationship between levels of metal pollution and density of vehicles.

The main measurements that can be taken against this situation are to perform exhaust controls in mobile stations to be placed on the road, and to minimize the levels of $\mathrm{Pb}$ added to gasoline. For this purpose, the use of lead-free gasoline in vehicles that are not common in the region, such 
as TIRs, trucks, automobiles, and buses should be encouraged. Moreover, the use of motor-oil additives containing high levels of $\mathrm{Ni}, \mathrm{Zn}$, and $\mathrm{Cr}$ and used especially by TIR and truck drivers in order to enhance engine performance should be forbidden. On the other hand, under the effects of heavy metal pollution caused from the intense vehicle traffic on D-755, the natural oriental plane population is in danger of extinction.

This is why the heavy metal pressure on oriental plane must be decreased by planting the species such as Prunus mahalep L., Thlaspi caerulescens L., Arabidopsis halleri L., Plantago zanceoluta L., Tamarix pamiflora L., Eucalyptus camaldulensis Dehn, Asplenium septentrionale (L.) Hoffm., Sorbus domestica L., Sorbus torminalis L., Festuca ovina Rich., and Paulownia tomentosa L., which are resistant to $\mathrm{Pb}, \mathrm{Ni}, \mathrm{Zn}, \mathrm{Cr}$, and $\mathrm{Cu}$, on the natural roadside corridors, and herbal support that protects the ecological balance must be ensured.

\section{Acknowledgements}

The authors thank the Turkey Highway General Directorate for database support and personnel of the Central Laboratory Directorate of Middle East Technical University (METU) and Central Laboratory Directorate of Düzce University for scientific and technical support.

\section{References}

1. YILMAZ R., SAKCALI S., YARCI C., AKSOY A., ÖZTÜRK M. Use of Aesculus hippocastanum L. as a Biomonitor of Heavy Metal Pollution. Pak. J. Bot. 38, (5), 1519, 2006.

2. ANONYMOUS The density of vehicle traffic in the Turkey. The Minister of Environment and Urbanization, Technical Report No:4, Ankara, pp. 135, 2014.

3. BILGE U., ÇIMRIN K.M. Heavy Metal Pollution in Soils
Adjacent to the Kiziltepe-Viranșehir. Journal of Agricultural Sciences 19, 323, 2013 [In Turkish].

4. ÇELIK A., ÇELIKK B.Y. Motor Vehicles and Environmental Pollution. Journal of Academic Platform 1, 209, 2013 [In Turkish].

5. DURU N., TÜRKMEN Z., ÇAVUŞOĞLU K., YALÇIN E., YAPAR K. Investigation of The Effects of Heavy Metal Pollution in Black Sea Seaside Caused from Vehicles by Using Verbascum sinuatum L. (Scrophulariaceae). Journal of Natural Sciences of Sakarya University 15, (2), 89, 2011 [In Turkish].

6. HASSAN I.A., BASAHI J.M. Assessing Roadside Conditions and Vehicular Emissions using Roadside Lettuce Plants. Pol. J. Environ. Stud. 22, (2), 387, 2013.

7. TERIM-KAPAKIN T.A. Transmission Electron Microscopy and Scaner Electron Microscopy, YYÜ Vet. Fak. Der. 18, (1), 105, 2007.

8. AMORIM J.H., VALENTE J., CASCAO P., RODRIGUES V., PIMENTEL C., MIRANDA A.I., BORREGO C. Pedestrian exposure to air pollution in cities: modeling the effect of roadside trees, Hindwai Publishing Advances in Meteorology 13, 1, 2013.

9. NEEMA N.M., JAHAN J. An innovative approach to mitigate vehicular emission through roadside greeneries: A case study on arterial roads of Dhaka city. Journal of Data Analysis and Information Processing 2, 32, 2014.

10. BELL J.N.B., HONOUR S.L., POWER S.A. Effects of vehiscle exhaust emissions on urban wild plant species. Environ. Pollut. 159, 1984, 2011.

11. ASLAM M., VERMA K.D., DHAKERYA R., RAIS S., ALAM M., ANSARI F.A. Bioindicator: A comparative study on uptake and accumulation of heavy metals in some plant's leaves of M.G. Road, Agra City, India. Research Journal of Environmental and Earth Science 4, (12), 1060, 2012.

12. TAIZ L., ZEIGER E. Plant Physiology, Sinauer Associates, Inc., Publishers. 2008.

13. ÖZEN H.Ç., ONAY A. Plant Physiology, Nobel Publisher. 2013 [In Turkish].

14. BRAUN M., MARGITAI Z., TOTH A., LEERMAKERS M. Environmental monitoring using linden tree leaves as natural traps of atmospheric deposition: A pilot study in Transilvania, Romania, AGD Landscape\&Environment 1, (1), 24, 2013 
